PREPARED FOR THE U.S. DEPARTMENT OF ENERGY, UNDER CONTRACT DE-AC02-76CH03073

PPPL-3669

PPPL-3669

UC-70

Fusion Power Deployment

by

J.A. Schmidt and J.M. Ogden

February 2002

$\left.\stackrel{N}{N}\right|_{\substack{\text { PRIncETOn PLASIMA } \\ \text { PHYSICS IABORATORY }}} ^{D}$

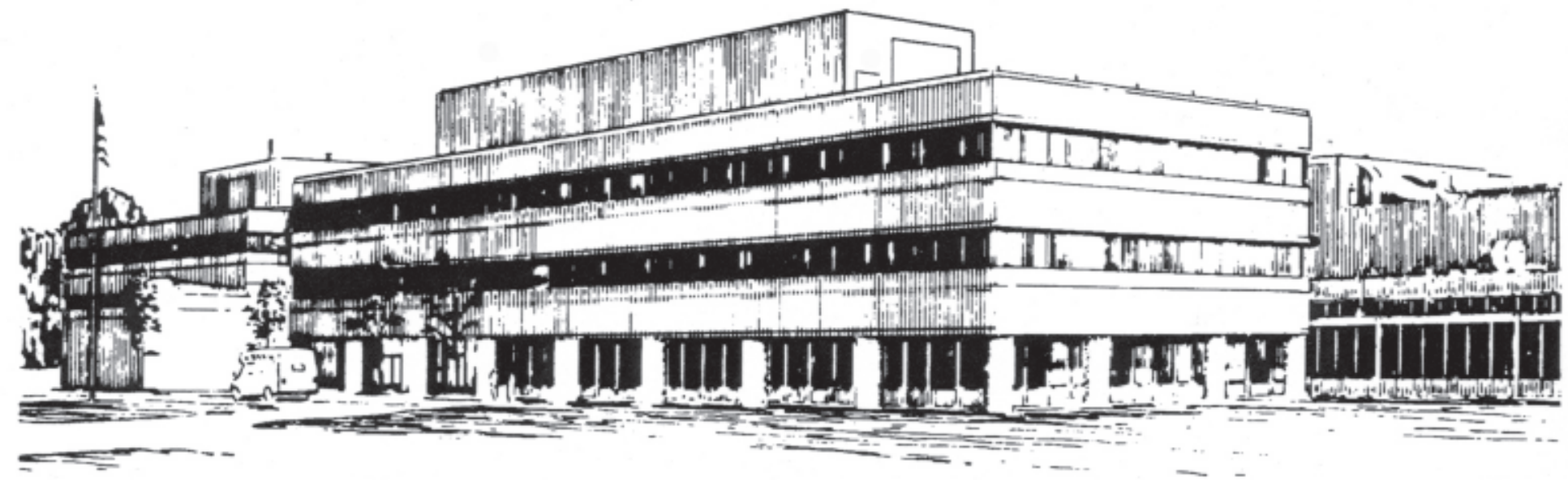

PRINCETON PLASMA PHYSICS LABORATORY PRINCETON UNIVERSITY, PRINCETON, NEW JERSEY 


\section{PPPL Reports Disclaimer}

This report was prepared as an account of work sponsored by an agency of the United States Government. Neither the United States Government nor any agency thereof, nor any of their employees, makes any warranty, express or implied, or assumes any legal liability or responsibility for the accuracy, completeness, or usefulness of any information, apparatus, product, or process disclosed, or represents that its use would not infringe privately owned rights. Reference herein to any specific commercial product, process, or service by trade name, trademark, manufacturer, or otherwise, does not necessarily constitute or imply its endorsement, recommendation, or favoring by the United States Government or any agency thereof. The views and opinions of authors expressed herein do not necessarily state or reflect those of the United States Government or any agency thereof.

\section{Availability}

This report is posted on the U.S. Department of Energy's Princeton Plasma Physics Laboratory Publications and Reports web site in Fiscal Year 2002. The home page for PPPL Reports and Publications is: http://www.pppl.gov/pub_report/

DOE and DOE Contractors can obtain copies of this report from:

U.S. Department of Energy

Office of Scientific and Technical Information

DOE Technical Information Services (DTIS)

P.O. Box 62

Oak Ridge, TN 37831

Telephone: (865) 576-8401

Fax: (865) 576-5728

Email: reports@adonis.osti.gov

This report is available to the general public from:

National Technical Information Service

U.S. Department of Commerce

5285 Port Royal Road

Springfield, VA 22161

Telephone: 1-800-553-6847 or

(703) 605-6000

Fax: (703) 321-8547

Internet: http://www.ntis.gov/ordering.htm 


\title{
FUSION POWER DEPLOYMENT
}

\section{J.A. SCHMIDT ${ }^{(1)}$ J.M. OGDEN ${ }^{(2)}$}

${ }^{1}$ Princeton Plasma Physics Laboratory, P.O. Box 451, MS 40, Princeton, New Jersey, 08543

(609) 243-2538 jschmidt@pppl.gov

\author{
${ }^{2}$ Center For Energy and Environmental Studies, Princeton University, \\ Princeton, New Jersey, 08544
}

(609) 258-5470 ogden@princeton.edu

\begin{abstract}
Fusion power plants could be part of a future portfolio of non-carbon dioxide producing energy supplies such as wind, solar, biomass, advanced fission power and fossil energy with carbon dioxide sequestration. In this paper, we discuss key issues that could impact fusion energy deployment during the last half of this century. These include geographic issues such as resource availability, scale issues, energy storage requirements and waste issues. The resource needs and waste production associated with fusion deployment in the U.S. should not pose serious problems. One important feature of fusion power is the fact that a fusion power plant should be locatable within most local or regional electrical distribution systems. For this reason fusion power plants should not increase the burden of long distance power transmission to our distribution system. In contrast to fusion power, regional factors could play an important role in the deployment of renewable resources such as wind, solar and biomass or fossil energy with $\mathrm{CO}_{2}$ sequestration. We examine the role of these regional factors and their implications for fusion power deployment.
\end{abstract}

\section{INTRODUCTION}

The need for alternate energy sources has become universally recognized. During the next century fossil fuel resources will probably be sufficient to satisfy world energy needs, however, the non-uniform geographic distribution of these resources creates security and balance of payments problems and often leads to increased and fluctuating costs. In addition air pollution from fossil fuel combustion is an increasing and 
expensive problem. The increase in carbon dioxide in the atmosphere from combustion of fossil fuels is receiving increased attention as a global problem.

The future deployment of new clean energy sources will clearly be in the form of a portfolio of technologies that could include wind, solar, biomass, fossil energy with carbon dioxide sequestration, advanced fission power and fusion. In this paper, we discuss key issues that could impact fusion energy deployment during the last half of this century, focussing on goals for viable fusion power, and regional and geographic issues such as resource availability.

Regional issues could be important for understanding fusion's future role, as compared to other options. It is likely that each energy supply technology would be implemented in regions that make best use of its respective strengths. For example wind power will tend to be deployed in regions with strong and constant winds and solar power will tend to be deployed in regions with high average solar exposure. Fossil energy complexes with $\mathrm{CO}_{2}$ capture and sequestration will be favored in areas with low cost fossil feedstocks and nearby disposal sites for $\mathrm{CO}_{2}$.

Renewable energy sources such as wind, solar and biomass tend to exhibit a cost per unit of energy that depends on the level of deployment in a given region (referred to in this paper as nonlinearity). This nonlinearity is related to the amount of resources available in a given region, to the temporal variability of energy sources such as wind and solar, and to the type of demand. These factors can play an important role in determining the mix of technologies deployed in a given region.

To illustrate non-linearity, consider biomass. Biomass wastes in the agricultural or forest products industries are very low cost feedstocks, but are available only at certain sites and are limited in quantity. Energy crops could be more widely available, but cost more. Eventually land use constraints limit the amount of locally available biomass. It is costly to transport biomass long distances, so local biomass feedstocks are preferred for energy production. As the level of biomass use increases in a certain area, biomass feedstocks and biomass energy tend to become progressively more costly.

As discussed below, fusion should be relatively insensitive to the level of deployment, and to the geographical location, making it potentially attractive in most regions. 


\section{FUSION GOALS AND CHARACTERISTICS}

To compare fusion to other energy sources it is important to list the relevant characteristics of the fusion reactor. Since we have not completed fusion development these characteristics can only be listed as goals.

Before widespread deployment, fusion must be developed as a baseload power source with high availability, and costs competitive with other low carbon emitting energy supplies. The breeding of tritium fuel must be at a level to support the deployment of new reactors without deployment rate limitations.

An important goal for fusion development is a commercial reactor that will not produce significant quantities of waste requiring long-term storage. Long-term waste storage is one of the most significant problems facing fission deployment.

Proliferation issues must be addressed for fusion, although this should prove to be much less of an issue than for fission (see below).

Fusion (and fission) power production will clearly be in the form of large baseload central power complexes with the associated production and transmission infrastructure. The regions that will be conducive to implementing fusion power systems will feature high population densities and large population centers.

It should be possible to site fusion reactors very near or within any power distribution system. In addition, fusion should be deployable at any level within a geographic area without increasing energy costs, at least for reactors in the $1 \mathrm{GW}$ range or less (At electric power plant sizes $>1 \mathrm{GW}$, there are some modest system costs for back-up power and transmission and distribution, Sheffield [1].) For these reasons, fusion should be considered a universally available large-scale energy source.

If fusion meets its development goals it should not present safety and long term waste storage problems and should be robust relative to proliferation and terrorist issues. The primary factor that will impact fusion deployment is whether it can be developed (and how long it will take) to meet its goals and the capital cost of the developed reactor. 


\section{ENERGY OPTIONS}

Future electric power systems will be a combination of energy options, optimized for the location being considered. In this section we discuss what characteristics make a location suitable or "fertile" for a given option, and compare fusion to other options. While most options have a significant geographic dependence and non-linearity, these are not important factors for fusion. If fusion meets its development goals it should be deployable as a baseload power technology within, or near, any power distribution system without regard to the number of other fusion reactors in the system. In the remainder of this section we discuss the important attributes of various future energy options, that will impact their deployment, and compare each option to fusion.

\section{Fission Power Deployment}

Fission is an established option with a solid database to support deployment decisions. The primary issues facing fission today are safety, waste and proliferation. If these issues can be addressed through technical development, to the satisfaction of the public and the associated political system, without significant added costs then fission power will be a very competitive and deployable option. The reason for developing fusion along side fission is the uncertainty that this goal can be realized. Fusion is relatively robust to proliferation risk since fissile material would not be present without detectable clandestine actions. Proliferation issues related to tritium and weapons science are judged (particularly for MFE) to be less threatening.

\section{Wind Power Deployment}

Wind power is a growing fraction of the world energy supply. Like fission, it is an option with an extensive database drawn from installed systems. In addition, there is a growing database on the availability of wind power sites for future development. The issue for future wind power deployment is the extent that wind variability and geographic limitations will place significant limitations on the level of deployment.

It is often stated that energy storage, with associated additional cost, can be integrated with a wind system to alleviate the problems with wind variability. However, energy storage should not be associated only with the wind component of the system. The storage system will in general store energy during periods of reduced demand (at night) and supply energy during periods of peak demand (during the afternoon). The source of stored energy will come from elements of the distribution system that have low fuel costs 
(e.g. wind, fusion). The energy storage can be readily charged irrespective of the existence of the wind farm. During periods of peak demand all systems will be called to provide power according to their capability (including the energy storage, wind and fusion). The point is that energy storage is a system wide element and will benefit the economics of other low fuel cost elements (fusion and wind).

\section{Solar Power Deployment}

Like wind power, there is a considerable base of experience with solar electric technologies, and ongoing rapid development. The competitiveness of solar power depends on the local source intensity, which varies strongly with location, on the type of demand and on future cost reductions in solar technologies. The solar resource is well matched to meeting peak electric demands, which tend to occur in the middle of hot summer days when there is abundant sunshine. Going beyond this level of deployment (e.g. using solar electricity for off-peak power) requires electric storage, which increases the cost of electricity. A recent study by Kelly and Weinberg [2] suggests that up to 15$30 \%$ of electric power might be supplied by intermittent renewables (solar and wind) for a California utility's load profiles.

\section{Carbon Capture and Sequestration}

Recently, it has been proposed that carbon dioxide could be captured, during production of electricity or fuels from fossil sources, and securely stored (or sequestered) where it cannot reach the atmosphere. Carbon sequestration could enable continued use of fossil energy, with near-zero emissions of carbon to the atmosphere.

Technologies exist for capturing carbon dioxide from power plants and fuel production processes (either from flue gases or from intermediate steps in chemical processes).

Systems for transporting and injecting $\mathrm{CO}_{2}$ underground have been developed in the oil industry, where $\mathrm{CO}_{2}$ is sometimes injected into oil fields to enhance oil recovery. Demonstration projects are underway in Norway and Canada to sequester $\mathrm{CO}_{2}$ in underground geological formations.

Significantly reducing carbon emissions from the energy system would require huge carbon storage capacity. Oil or gas reservoirs are attractive as storage sites for $\mathrm{CO}_{2}$, having proven ability to store gas for long periods of time. However, they are relatively small compared to carbon flows in the energy system, and are clustered in oil and gas producing regions. Deep saline aquifers are widely distributed geographically, and are 
potentially a much larger resource, but not all aquifers could provide secure $\mathrm{CO}_{2}$ storage for many thousands of years. Current estimates of total underground geological carbon storage capacity are uncertain, but if mid-range estimates are correct, secure underground storage could, take up all the carbon from fossil energy use for hundreds of years. The deep ocean is another potentially huge storage site, although concerns have been raised about the possible environmental effects of $\mathrm{CO}_{2}$ injection in the ocean.

Like fusion plants, fossil energy complexes with $\mathrm{CO}_{2}$ sequestration would be large, baseload plants that could produce both electricity and fuels (hydrogen), and could be sited in most places in the world. Fossil energy complexes with $\mathrm{CO}_{2}$ capture will be similar in scale to coal-fired power plants today (about $1 \mathrm{GW}$ of electrical capacity). The main geographic constraints will be the availability of low cost fossil fuel feedstocks and the proximity to suitable disposal sites for $\mathrm{CO}_{2}$ such as deep saline aquifers or depleted oil or gas fields. In the United States, most fossil energy plants are close to potential sites for sequestration. Above a certain level of deployment, nearby reservoirs might be filled and more distant sequestration sites might be required. However, the cost of pipeline transmission per unit of $\mathrm{CO}_{2}$ decreases with higher flow rates, so overall, there might be relatively little non-linearity.

\section{ROLE OF HYDROGEN}

Currently, direct combustion of fuels for transportation and heating accounts for over $2 / 3$ of global primary energy consumption, and a majority of emissions of air pollutants and greenhouse gases. Many see hydrogen as a possible low polluting replacement for current fuels, hydrogen being a complementary energy carrier to electricity in a future energy system with near zero emissions of greenhouse gases and pollutants.

\section{Hydrogen as a Future Transportation Fuel}

Of the many alternative vehicles and fuels that have been proposed, hydrogen used in fuel cell vehicles appears to offer the lowest full fuel cycle (or "well-to-wheels") emissions of pollutants and greenhouse gases. Moreover, hydrogen can be made from a variety of widely available primary energy sources including fossil fuels, biomass, solar, wind and nuclear power. Hydrogen vehicles and fuel cells are undergoing rapid development worldwide, and being demonstrated in fleet operations. Most major automakers have developed experimental fuel cell cars, with several planning to commercialize within the next 5 years. 


\section{Role for Hydrogen from Off-peak Power}

Hydrogen could be produced at competitive costs via water electrolysis, if off-peak electrical power were available at very low costs ( 1 cents/kWh). (Off-peak is defined as those hours where the utility system electrical demand is low, generally at night.) Hydrogen from off-peak power could make small, but locally significant contributions to serving future global hydrogen demand. Globally, direct fuel use for transportation and heating accounts for over twice as much primary energy consumption as electric generation. Thus, electrolytic hydrogen from off-peak power could meet only a small fraction of total fuel demand, and globally other hydrogen sources would be needed, Williams [3], if hydrogen became a major fuel. A recent study by Sheffield [1] indicated that hydrogen produced from off-peak fusion power might become competitive with other low-carbon sources of hydrogen (e.g. hydrogen from decarbonized fossil sources or renewables), if fusion meets all its performance and cost goals, and if on-peak power from the fusion plant could be sold at 6-8 cents/kWh. Hydrogen from dedicated fusion powered electrolysis plants was too costly to compete with thermochemical hydrogen production. Fusion's contribution to off-peak power might be used to make hydrogen fuel. However, most hydrogen would come from other sources, such as decarbonized fossil fuels or renewables where these are available

\section{Regional Issues and Long Distance Transport of Hydrogen}

Like electricity, hydrogen is an energy carrier that can be produced from a variety of primary sources at a range of scales. The best hydrogen supply is regionally specific, depending on the locally available resources, and the level and type of demand. At large energy flow rates, hydrogen can be transported long distances via high pressure gas pipelines at modest cost, but ocean transport is problematic, as hydrogen must be liquefied for shipping in tankers incurring both high costs and large energy penalties. It is likely that hydrogen energy supplies will be regional, more similar to today's electricity system than to current oil supply. Options like fusion, which have few geographic limitations, will become more competitive for locations that are geographically removed particularly from sources of renewable or decarbonized fossil energy. 


\section{CONCLUSIONS}

If fusion successfully meets cost and performance goals, it can be regarded as a universally available large-scale baseload power source that could be sited almost anywhere. The competitiveness of fusion with other long term zero carbon options like wind, solar, biomass, and decarbonized fossil fuels is strongly dependent on location, due primarily to the geographic dependence of alternate options. In a similar manner, fusion competitiveness is connected with the relatively strong dependence of the cost of electricity for alternate options on their level of deployment. The role energy storage is more related to optimizing the energy supply system to meet peak demand than it is to alleviate problems with individual source variability. Fusion's contribution to off-peak power might be used to make hydrogen fuel at competitive costs. However, most hydrogen would come from other sources, if hydrogen becomes a major energy carrier. 


\section{References:}

[1] John Sheffield, William Brown, Gary Garrett, James Hilley, Dennis McCloud, Joan Ogden, Thomas Shields, Lester Waganer, "Study of Options for the Deployment of Large Fusion Power Plants," Fusion Science and Technology, 40 (July 2001) 1-36

[2] Henry Kelly and Carl J. Weinberg, Renewable Energy, Sources for Fuels and Electricity, edited by Thomas B. Johansson ... [et al.] (1993 Island Press) Chapter 23

[3] Robert H. Williams, "Nuclear and Alternative Energy Supply Options for an Environmentally Constrained World: A Long-term Perspective." To be published. 


\section{External Distribution}

Plasma Research Laboratory, Australian National University, Australia

Professor I.R. J ones, Flinders University, Australia

Professor J oão Canalle, Instituto de Fisica DEQ/IF - UERJ , Brazil

Mr. Gerson O. Ludwig, Instituto Nacional de Pesquisas, Brazil

Dr. P.H. Sakanaka, Instituto Fisica, Brazil

The Librarian, Culham Laboratory, England

Library, R61, Rutherford Appleton Laboratory, England

Mrs. S.A. Hutchinson, JET Library, England

Professor M.N. Bussac, Ecole Polytechnique, France

Librarian, Max-Planck-Institut für Plasmaphysik, Germany

J olan Moldvai, Reports Library, MTA KFKI-ATKI, Hungary

Dr. P. Kaw, Institute for Plasma Research, India

Ms. P.J . Pathak, Librarian, Insitute for Plasma Research, India

Ms. Clelia De Palo, Associazione EURATOM-ENEA, I taly

Dr. G. Grosso, Instituto di Fisica del Plasma, Italy

Librarian, Naka Fusion Research Establishment, J AERI, J apan

Library, Plasma Physics Laboratory, Kyoto University, J apan

Research Information Center, National Institute for Fusion Science, J apan

Dr. O. Mitarai, Kyushu Tokai University, J apan

Library, Academia Sinica, Institute of Plasma Physics, People's Republic of China

Shih-Tung Tsai, Institute of Physics, Chinese Academy of Sciences, People's Republic of China

Dr. S. Mirnov, TRINITI, Troitsk, Russian Federation, Russia

Dr. V.S. Strelkov, Kurchatov Institute, Russian Federation, Russia

Professor Peter Lukac, Katedra Fyziky Plazmy MFF UK, Mlynska dolina F-2, Komenskeho Univerzita, SK-842 15 Bratislava, Slovakia

Dr. G.S. Lee, Korea Basic Science Institute, South Korea

Mr. Dennis Bruggink, Fusion Library, University of Wisconsin, USA

Institute for Plasma Research, University of Maryland, USA

Librarian, Fusion Energy Division, Oak Ridge National Laboratory, USA

Librarian, Institute of Fusion Studies, University of Texas, USA

Librarian, Magnetic Fusion Program, Lawrence Livermore National Laboratory, USA

Library, General Atomics, USA

Plasma Physics Group, Fusion Energy Research Program, University of California at San Diego, USA

Plasma Physics Library, Columbia University, USA

Alkesh Punjabi, Center for Fusion Research and Training, Hampton University, USA

Dr. W.M. Stacey, Fusion Research Center, Georgia Institute of Technology, USA

Dr. J ohn Willis, U.S. Department of Energy, Office of Fusion Energy Sciences, USA

Mr. Paul H. Wright, Indianapolis, Indiana, USA 
The Princeton Plasma Physics Laboratory is operated by Princeton University under contract with the U.S. Department of Energy.

\author{
Information Services \\ Princeton Plasma Physics Laboratory \\ P.O. Box 451 \\ Princeton, NJ 08543
}

Phone: 609-243-2750

Fax: 609-243-2751

e-mail: pppl_info@pppl.gov

Internet Address: http://www.pppl.gov 